\title{
Glutamine potently stimulates glucagon-like peptide-1 secretion from GLUTag cells
}

\author{
F. Reimann ${ }^{1}$ - L. Williams ${ }^{1}$ - G. da Silva Xavier ${ }^{2}$ - G. A. Rutter ${ }^{2}$ - F. M. Gribble 1 \\ ${ }^{1}$ Cambridge Institute for Medical Research, Wellcome Trust/MRC Building, Addenbrooke's Hospital, Cambridge, UK \\ ${ }^{2}$ Henry Wellcome Laboratories for Integrated Cell Signalling and Department of Biochemistry, School of Medical Sciences, \\ University of Bristol, UK
}

\section{Abstract}

Aims/hypothesis. Glucagon-like peptide-1 (GLP-1) and peptide YY (PYY) are secreted from enteroendocrine $\mathrm{L}$ cells in response to nutrient ingestion. As glutamine is an important metabolic fuel for the gut, the aim of this study was to investigate the effect of glutamine on the GLP-1-secreting cell line, GLUTag.

Methods. GLP-1 release was measured following incubation of GLUTag cells under a range of conditions. Single cells were studied by electrophysiology, calcium imaging and cytosolic ATP measurement using recombinant luciferase.

Results. Glutamine was a more potent GLP-1 secretagogue than glucose or other amino acids, increasing GLP-1 release $7.1 \pm 0.7$-fold $(n=19)$ at $10 \mathrm{mmol} / \mathrm{l}$, with an estimated median effective concentration of between 0.1 and $1 \mathrm{mmol} / \mathrm{l}$. Glutamine $(10 \mathrm{mmol} / \mathrm{l})$ induced a sodium-dependent inward current of $3.2 \pm 1.2 \mathrm{pA}$ per cell $(n=9)$, which triggered membrane depolarisation and an increase in intracellular calcium. Asparagine and alanine produced electrophysiological and calcium changes that were at least as large as those caused by glutamine, but they were less effective GLP-1 secretagogues, suggesting that glutamine also potentiates secretion downstream of the calcium signal. This was confirmed by measuring secretion in the presence of $30 \mathrm{mmol} / \mathrm{l} \mathrm{KCl}+$ diazoxide, or in $\alpha$-haemolysin-permeabilised cells. Glutamine increased cytosolic ATP, but was less effective than glucose.

Conclusions/interpretation. Glutamine acts as a trigger and potentiator of GLP-1 release, consistent with its role as the major metabolic fuel for the gut. The results suggest that nutritional agents like glutamine might have beneficial effects in diabetes and obesity.

Keywords Diabetes - Glucagon-like peptide-1 · GLUTag cells · Glutamine · Obesity

\section{Introduction}

Intestinal neuroendocrine L cells secrete glucagonlike peptides-1 and -2 (GLP-1, GLP-2) and peptide YY (PYY) in response to food ingestion $[1,2,3,4,5$, 6]. GLP-1 and PYY modulate glucose homeostasis

Received: 22 March 2004 / Accepted: 2 June 2004

Published online: 9 September 2004

(C) Springer-Verlag 2004

F. M. Gribble (ه)

Cambridge Institute for Medical Research,

Wellcome Trust/MRC Building, Addenbrooke's Hospital,

Hills Road, Cambridge, CB2 2XY, UK

E-mail: fmg23@cam.ac.uk

Tel.: +44-1223-336746, Fax: +44-1223-762323 and energy balance: GLP-1 by enhancing insulin release [7], and PYY by increasing satiety [8]. These peptides are therefore under investigation as candidates for the treatment of Type 2 diabetes and obesity. GLP-2 affects gut motility and is an intestinal trophic factor, with therapeutic potential for the treatment of intestinal disorders such as short bowel syndrome [9].

Abbreviations: BCH, 2-amino-2-norbornanecarboxylic acid · CaM, calmodulin - DON, 6-diaza-5-oxo-L-norleucine · GDH, glutamate dehydrogenase - GLP-1, glucagon-like peptide-1 · GLP-2, glucagon-like peptide-2 · IBMX, 3-isobutyl-1-methylxanthine $\cdot \mathrm{K}_{\text {ATP }}$ channel, ATP-sensitive potassium channel - MeAIB, $\alpha$ (methylamino)isobutyric acid . NMDG, $N$-methyl-D-glucamine $\cdot$ PKA, protein kinase A . PKC, protein kinase C $\cdot$ PYY, peptide YY 
Developing strategies to enhance secretion from intestinal $\mathrm{L}$ cells could therefore provide alternative therapies for a range of conditions, including Type 2 diabetes and obesity.

Secretion from L cells in vivo occurs in response to various components of the diet, including carbohydrates, fats and proteins $[10,11,12]$. The mechanisms underlying the stimulation of secretion remain uncertain, although there is evidence for both direct $\mathrm{L}$ cell sensing of the luminal contents and indirect pathways involving neural/hormonal components [2, 13]. Using the murine GLP-1-secreting cell line, GLUTag, we have previously shown that GLP-1-secreting cells are electrically active and respond directly to increases in the glucose concentration by enhanced action potential firing and GLP-1 release $[14,15]$. The mechanism partly resembles that found in the pancreatic beta cell, involving closure of ATP-sensitive potassium $\left(\mathrm{K}_{\mathrm{ATP}}\right)$ channels [14], but in GLUTag cells an additional depolarising stimulus is provided by electrogenic coupled $\mathrm{Na}^{+}$and glucose entry via sodium-coupled glucose cotransporters [15].

Although protein has been found to stimulate GLP1 release in a number of studies $[10,11,16]$, the underlying mechanism has not been elucidated and some controversy remains about the effectiveness of protein on the L cell [17]. Whereas protein hydrolysate and peptones have been found to stimulate $\mathrm{L}$ cell secretion in several studies $[18,19,20]$, amino acid mixtures are a less reliable stimulus $[11,12,20]$. Interestingly, however, the amino acid mixtures tested did not contain glutamine, which is believed to be a major energy source for the gut $[21,22]$. Glutamine has a number of beneficial effects on the gut, not all of which can be accounted for by its metabolism alone [22], and it is used therapeutically as a nutritional supplement in conditions such as parenteral nutrition and cancer chemotherapy [23]. The question, therefore, arises as to whether L cells, like other intestinal cells, are sensitive to changes in the glutamine concentration.

In this paper, we have investigated the effect of glutamine on GLP-1-secreting cells using the cell line GLUTag [24]. This cell line was originally derived from a colonic tumour in a transgenic mouse expressing SV40 large $\mathrm{T}$ antigen under the control of the proglucagon promoter. It has been shown to respond to a range of physiological stimuli and is believed to be a good model cell line of GLP-1 secretion. We used a variety of techniques, including electrophysiology, intracellular calcium imaging, dynamic cytosolic ATP measurements and assays of GLP-1 release, to investigate the mechanisms underlying the effect of glutamine on GLP-1 secretion.

\section{Materials and methods}

Cell culture. GLUTag cells [24] were cultured in DMEM (5.5 mmol/l glucose), as described previously [14].

GLP-1 secretion. For secretion experiments cells were plated in 24-well culture plates and allowed to reach 60 to $80 \%$ confluency. On the day of the experiment, cells were washed twice with $500 \mu \mathrm{l}$ nutrient-free KRB containing (mmol/l): $120 \mathrm{NaCl}$, $5 \mathrm{KCl}, 2 \mathrm{CaCl}_{2}, 1 \mathrm{MgCl}_{2}, 22 \mathrm{NaHCO}_{3}$, and 0.1 Diprotin A, bubbled with $95 \% \mathrm{O}_{2} / 5 \% \mathrm{CO}_{2}$ for $10 \mathrm{~min}$ and supplemented with $0.5 \%(\mathrm{w} / \mathrm{v}) \mathrm{BSA}$. Experiments were performed by incubating the cells with test reagents in $500 \mu \mathrm{KRB}$ for $2 \mathrm{~h}$ at $37{ }^{\circ} \mathrm{C}, 5 \% \mathrm{CO}_{2}$. In some experiments the $\mathrm{KCl}$ concentration was increased to $30 \mathrm{mmol} / \mathrm{l}(\mathrm{NaCl}$ was reduced accordingly to $95 \mathrm{mmol} / \mathrm{l}$ ) and $0.34 \mathrm{mmol} / \mathrm{l}$ diazoxide was added. IBMX, forskolin, KN93, H89, BIM-I and rapamycin were prepared as $1000 \times$ stocks in DMSO and the final DMSO concentration was adjusted to $0.25 \%$ for all conditions tested, including the control. Other test agents were directly dissolved in KRB and the $\mathrm{pH}$ was readjusted to 7.4 with $\mathrm{NaOH}$ or $\mathrm{HCl}$. At the end of the incubation period, medium was collected and centrifuged to remove any floating cells. GLP-1 was assayed using an ELISA specific for GLP-1(7-36 amide) and GLP-1(7-37) (Linco GLP-1 active ELISA-kit; Biogenesis, Poole, UK). Secretion was normalised to the baseline release in the absence of nutrients measured in parallel on the same day. This baseline secretory rate was $28.5 \pm 2.6 \mathrm{fmol}$ per dish in $2 \mathrm{~h}(n=37)$. To measure the time course of GLP-1 release, cells were incubated for different times in the presence or absence of glutamine, and the GLP-1 content of the medium was assayed as above.

Permeabilisation of cells. Cells were plated in Matrigel-coated 24-well culture plates (Matrigel supplied by BD Biosciences, Fahrenheit, Milton Keynes, UK), and allowed to reach 60 to $80 \%$ confluency. Secretion experiments in KRB with a range of different secretagogues revealed no difference in the responsiveness of cells cultured with or without Matrigel. On the day of the experiment, wells were washed twice with $500 \mu \mathrm{Ca}^{2+}$ free buffer containing (mmol/l): $135 \mathrm{NaCl}, 5 \mathrm{KCl}, 2 \mathrm{NaHCO}_{3}$, $0.5 \mathrm{NaH}_{2} \mathrm{PO}_{4}, 0.5 \mathrm{MgCl}_{2}, 0.4$ EGTA, 10 HEPES (pH 7.4 with $\mathrm{NaOH}$ ). Permeabilisation was achieved by incubating for 15 min at $37{ }^{\circ} \mathrm{C}$ with approximately 69 units of Staphylococcus aureus $\alpha$-haemolysin in $100 \mu$ lysis buffer containing (mmol/l): $107 \mathrm{KCl}, 5 \mathrm{NaCl}, 7 \mathrm{MgSO}_{4}, 20 \mathrm{HEPES}, 10.2$ EGTA, $1.65 \mathrm{CaCl}_{2}, 1 \mathrm{~K}_{2} \mathrm{ATP}, 0.1 \% \mathrm{BSA}\left(\mathrm{pH} 7.0\right.$ with $\mathrm{KOH}$; final $\left[\mathrm{K}^{+}\right]$ $\sim 140 \mathrm{mmol} / \mathrm{l})$. In some control wells permeabilisation was assessed by subsequent incubation with $0.4 \%$ Eosin $\mathrm{Y}$ in lysis buffer for $5 \mathrm{~min}$ at $37{ }^{\circ} \mathrm{C}$, which stained more than $90 \%$ of cells (compared with less than $5 \%$ of cells stained in wells not exposed to the toxin). The cells were subsequently washed with $250 \mu \mathrm{l}$ lysis buffer, incubated for 15 min with $500 \mu \mathrm{l}$ lysis buffer, and incubated for $10 \mathrm{~min}$ in $500 \mu \mathrm{l}$ stimulation buffer (similar to lysis buffer but with 0 or $5 \mathrm{mmol} / \mathrm{l} \mathrm{ATP}$ and 1.65 or $6.65 \mathrm{mmol} / 1 \mathrm{CaCl}_{2}$ ) at $37{ }^{\circ} \mathrm{C}, 5 \% \mathrm{CO}_{2}$. The free $\mathrm{Ca}^{2+}$ concentrations of the lysis and stimulation buffer were estimated at $121 \mathrm{nmol} / \mathrm{l}$ (for $1.65 \mathrm{mmol} / \mathrm{l} \mathrm{CaCl}{ }_{2}$ ) and 1.2 to $1.4 \mu \mathrm{mol} / \mathrm{l}$ (for $6.65 \mathrm{mmol} / \mathrm{l} \mathrm{CaCl}_{2}$ ), respectively, using BAD4-software [25]. DON, when included, was also present during the final $10 \mathrm{~min}$ of the pre-incubation. Experiments were performed by incubating the cells with test reagents in $500 \mu \mathrm{l}$ stimulation buffer for $1 \mathrm{~h}$ at $37{ }^{\circ} \mathrm{C}, 5 \% \mathrm{CO}_{2}$. GLP-1 secretion was assayed by ELISA as above.

Electrophysiology. Cells were plated into $35-\mathrm{mm}$ dishes 1 to 3 days prior to use. Experiments were performed on single cells and well-defined cells in small clusters. Microelectrodes 
were pulled from borosilicate glass (GC150T; Harvard Apparatus, Edenbridge, UK) and the tips coated with refined yellow beeswax. Electrodes were fire-polished using a microforge (Narishige, London, UK) and had resistances of 2.5 to $3 \mathrm{M} \Omega$ when filled with pipette solution. Membrane potential and currents were recorded using an Axopatch 200B (Axon Instruments, Union City, Calif., USA) linked through a Digidata 1320A interface, and analysed using pCLAMP software (Axon Instruments). All electrophysiological recordings were made using the perforated patch configuration of the patch clamp setup at 22 to $24{ }^{\circ} \mathrm{C}$. Membrane conductance was measured in voltage clamp experiments by applying a series of 1.2 -s voltage ramps from -90 to $-50 \mathrm{mV}$ (holding potential $-70 \mathrm{mV}$ ). The current voltage relation was linear in this voltage range, and the slope conductance was calculated from the average of more than ten voltage ramps.

$\mathrm{Ca}^{2+}$ measurements. Cells were plated on Matrigel-coated coverslips 1 to 3 days prior to use, and loaded with fura- 2 by incubation in $1 \mu \mathrm{mol} / \mathrm{l}$ of the acetoxymethylester (Molecular Probes, Leiden, The Netherlands) for $30 \mathrm{~min}$ at $37{ }^{\circ} \mathrm{C}$ in bath solution containing $1 \mathrm{mmol} / \mathrm{l}$ glucose. Measurements were taken after mounting the coverslip in a perfusion chamber (Warner Instruments, Harvard Apparatus) on an inverted fluorescence microscope (Olympus IX71, Southall, UK) with a $40 \times$ oil immersion objective. Excitation at 340 and $380 \mathrm{~nm}$ was achieved using a combination of a 75-W Xenon arc lamp and a monochromator (Cairn Research, Faversham, UK) controlled by MetaFluor software (Universal Imaging, Cairn), and emission was recorded with a CCD camera (Orca ER; Hammamatsu, Cairn) using a dichroic mirror and a 510-nm long pass filter. Free cytoplasmic $\mathrm{Ca}^{2+}$ concentrations were estimated for individual cells from background-subtracted fluorescence using the equation of Grynkiewicz [26] assuming a $K_{\mathrm{d}}$ of $224 \mathrm{nmol} / \mathrm{l}$. Minimal and maximal signals were recorded in the presence of $5 \mu \mathrm{mol} / \mathrm{l}$ ionomycin in $5 \mathrm{mmol} / 1 \mathrm{EGTA} / 0 \mathrm{mmol} / \mathrm{l} \mathrm{Ca}{ }^{2+}$ and $5 \mathrm{mmol} / \mathrm{l} \mathrm{Ca}^{2+}$, respectively, at the end of the experiment.

Solutions and chemicals. The bath solution contained (mmol/l): $5.6 \mathrm{KCl}, 138 \mathrm{NaCl}, 4.2 \mathrm{NaHCO}_{3}, 1.2 \mathrm{NaH}_{2} \mathrm{PO}_{4}, 2.6 \mathrm{CaCl}_{2}$, $1.2 \mathrm{MgCl}_{2}, 10$ HEPES (pH 7.4). Amino acids and drugs were added to the bath solution as indicated. The $\mathrm{Na}^{+}$-free bath solution contained (mmol/l): 148.4 NMDG, $4.4 \quad \mathrm{KHCO}_{3}$, $1.2 \mathrm{KH}_{2} \mathrm{PO}_{4}, 2.6 \mathrm{CaCl}_{2}, 1.2 \mathrm{MgCl}_{2}, 10$ HEPES (pH 7.4 with $\mathrm{HCl})$. The perforated patch pipette solution contained $(\mathrm{mmol} / \mathrm{l})$ : $76 \mathrm{~K}_{2} \mathrm{SO}_{4}, 10 \mathrm{KCl}, 10 \mathrm{NaCl}, 55$ sucrose, 10 HEPES, $1 \mathrm{MgCl}_{2}$ ( $\mathrm{pH} 7.2$ ), to which amphotericin $\mathrm{B}$ was added to a final concentration of $200 \mu \mathrm{g} / \mathrm{ml}$. Drugs and chemicals were purchased from Sigma-Aldrich (Poole, UK) unless otherwise stated. H89, KN93, BIM-1, rapamycin and ionomycin were purchased from Calbiochem (Merck Eurolab, Lutterworth, UK) and DON from Bachem (Merseyside, UK).

Measurement of cytosolic free ATP concentration. Cells plated on glass coverslips were infected with adenoviruses encoding humanised firefly luciferase (Promega, Southampton, UK) under cytomegalovirus promoter control [27]. Changes in cytosolic ATP were measured $24 \mathrm{~h}$ after infection. Single-cell photon counting was performed using an Olympus IX-70 microscope fitted with a $\times 10$ air objective, 0.4 numerical aperture, and a Photek ICCD218 intensified camera (Photek, Lewes, UK) as previously described [27, 28]. Cells were cultured in $0 \mathrm{mmol} / \mathrm{l}$ glucose and then stimulated with $10 \mathrm{mmol} / \mathrm{l}$ glutamine or $1 \mathrm{mmol} / \mathrm{l}$ glucose.

Statistical analysis. Results are presented as means \pm SE. Statistical significance was tested in the first case by ANOVA, and subsequently by one-sample or unpaired Student's $t$ tests (as indicated). A $p$ value of less than 0.05 was considered statistically significant.

$R T-P C R$. As previously described [14], RT-PCR was performed using the following specific primers, which were designed using sequence information obtained from http://www. ensembl.org/mus_musculus/ (from $5^{\prime}$ to $3^{\prime}$ ): SLC38A1/ATA1 sense TCGGGAGAGTAGGAGGAGTC, antisense GCTCCACACTCATGCAGGG; SLC38A2/ATA2 sense ACAGACTTTCATCCAGGTACTAC, antisense TTCACAGTTTCGTTGGCCACC; SLC38A3/SN1 sense CCAACACTGTGGAGAGGGC, antisense CCTCTGCCACCACCATGTG; SLC38A4/ATA3 sense ACGCGGATGAGCATCACCC, antisense TGTTGTGATCCAGAGCAGGC; SLC38A5/SN2 sense CTGCCCACCACCCGTAACC, antisense TTCAGCCTCCACTACTGTGTC; SLC7A6/y+LAT2 sense GTGTCAGGGACACACTGAGC, antisense GACATCCTGAATGTTCAGCACTG; SLC7A7/y+LAT1 sense TTGGCCAGGGAGCCACAGC, antisense CTGGAAGCAGCCACGATGG; SLC6A14/ATB ${ }^{o,+}$ sense TCTGACCTACACCAATGGCG, antisense CACTGGGAAGTTGTCCTGGC; SLC1A7/mASCT2 sense TGCTGACGCGCTGGGTCC, antisense CCGCTGGATACAGGATTGCG. The predicted sizes (bp) of fragments were: (ATA1) 611, (ATA2) 583, (SN1) 715, (ATA3) 576, (SN2) 624, (y+LAT2) 251, (y+LAT1) 382, $\left(\mathrm{ATB}^{\circ,+}\right) 440$, (mASCT2) 448. All primer pairs span intron-exon borders to distinguish amplification from genomic DNA. No bands were amplified when $\mathrm{H}_{2} \mathrm{O}$ was used instead of cDNA. Identity of amplified bands was confirmed by sequencing.

\section{Results}

To investigate whether glutamine stimulates GLP-1 release from GLUTag cells, we cultured cells in $10 \mathrm{mmol} / \mathrm{l}$ glutamine or $10 \mathrm{mmol} / \mathrm{l}$ glucose for 2 hours. As reported previously $[14,15]$, glucose stimulated GLP-1 secretion, which increased approximately three-fold. Glutamine was a more potent stimulus, enhancing secretion approximately seven-fold at $10 \mathrm{mmol} / \mathrm{l}$ (Fig. 1a), with an estimated median effective concentration of between 0.1 and $1 \mathrm{mmol} / \mathrm{l}$ (Fig. 1b). A time course study showed that $10 \mathrm{mmol} / \mathrm{l}$ glutamine enhanced GLP-1 release within minutes of its application, with a subsequent slow increase in the rate of secretion over 2 hours (Fig. 1c). A range of other amino acids (each at $10 \mathrm{mmol} / \mathrm{l}$ ) also stimulated GLP-1 release (Fig. 1a), but none were as effective as glutamine ( $t$ test vs glutamine $p<0.05$ for all agents tested).

Electrophysiological response to glutamine. Glutamine $(10 \mathrm{mmol} / \mathrm{l})$ potently triggered action potentials in GLUTag cells recorded in the perforated patch configuration. While asparagine stimulated the firing of action potentials as strongly as glutamine, glutamate was much less effective (Fig. 2a, b). To investigate the underlying mechanism, we applied a series of voltage ramps in the absence and presence of amino acids. Glutamine shifted the current voltage relationship downwards, corresponding to an increase in the in- 
ward current at $-70 \mathrm{mV}$ of $3.2 \mathrm{pA} /$ cell (Fig. 2c, d), with no significant effect on the slope conductance. A current of similar magnitude was induced by asparagine $(10 \mathrm{mmol} / \mathrm{l}$; Fig. 2d). Substitution of extracellular $\mathrm{Na}^{+}$with $\mathrm{NMDG}^{+}$abolished the response to glutamine (Fig. 2d). These data are consistent with the idea that glutamine and asparagine trigger action potentials by electrogenic amino acid uptake coupled to $\mathrm{Na}^{+}$influx.
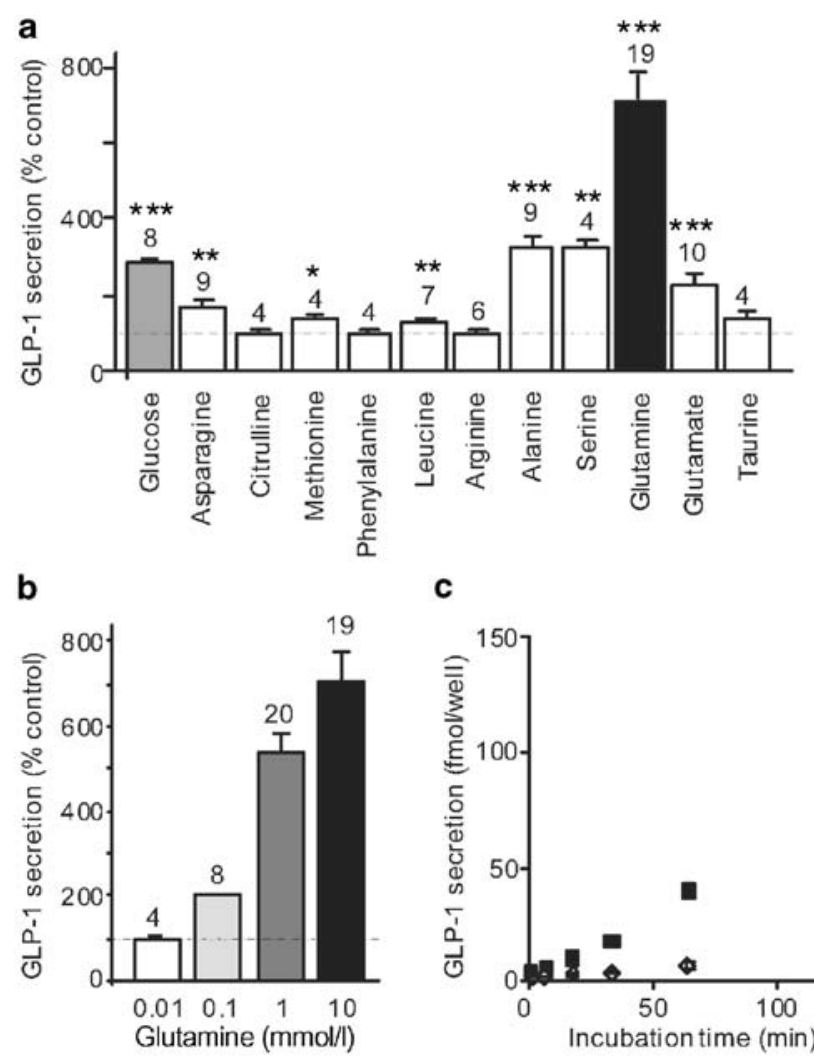

C

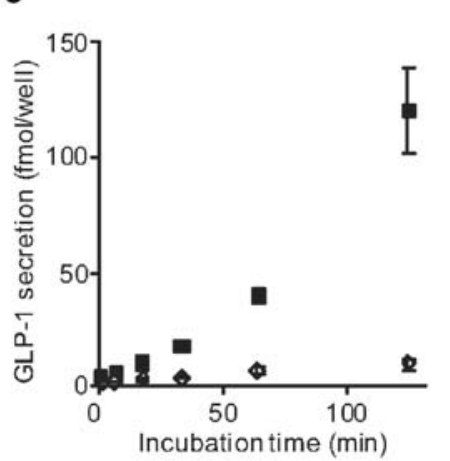

Effect of glutamine and glucose on intracellular free ATP concentration. We reported previously that $\mathrm{K}_{\text {ATP }}$ channel closure contributes to the electrical response to glucose in GLUTag cells. The lack of change in the slope conductance upon addition of glutamine, however, does not support the idea that $\mathrm{K}_{\text {ATP }}$ channel closure also underlies the response to glutamine. We examined this idea further by measuring dynamic changes in the ATP concentration using recombinant luciferase and bioluminescence imaging. Addition of $10 \mathrm{mmol} / \mathrm{l}$ glutamine in the presence of $0 \mathrm{mmol} / \mathrm{l}$ glucose led to a $10 \pm 4 \%$ increase in apparent free cytosolic ATP (Fig. 3a). Subsequent addition of $1 \mathrm{mmol} / \mathrm{l}$ glucose led to a substantially greater $(23 \pm 5 \%)$ further increase in ATP (Fig. 3a). When the order of addition was reversed (Fig. 3b), $1 \mathrm{mmol} / \mathrm{l}$ glucose prompted a $57 \pm 9 \%$ increase in cytosolic ATP, whereas $10 \mathrm{mmol} / \mathrm{l}$ glutamine caused an $18 \pm 9 \%$ increase. Thus, glutamine was less effective than glucose at raising cytosolic ATP when added as the first or second substrate. The

Fig. 1. Secretory responses of GLUTag cells to glutamine. a. GLP-1 secretion from GLUTag cells cultured with $10 \mathrm{mmol} / \mathrm{l}$ glucose or the amino acid indicated. The number of wells is indicated above each bar. Statistical significance was assessed relative to secretion in the absence of nutrients using Student's one-sample $t$ test: $* * * p<0.001, * * p<0.01, * p<0.05$. Where bars are not marked with asterisks, results were not significant. b. Concentration dependence of glutamine-induced secretion. Secretion in $\mathbf{a}$ and $\mathbf{b}$ was normalised to baseline secretion in the absence of nutrients, measured in parallel on the same day. In $\mathbf{a}$ and $\mathbf{b}$ the $10 \mathrm{mmol} / \mathrm{l}$ glutamine data is the same. c. Time course of GLP-1 release in the absence (open diamonds) or presence (closed squares) of $10 \mathrm{mmol} / \mathrm{l}$ glutamine. $n=4$ per point
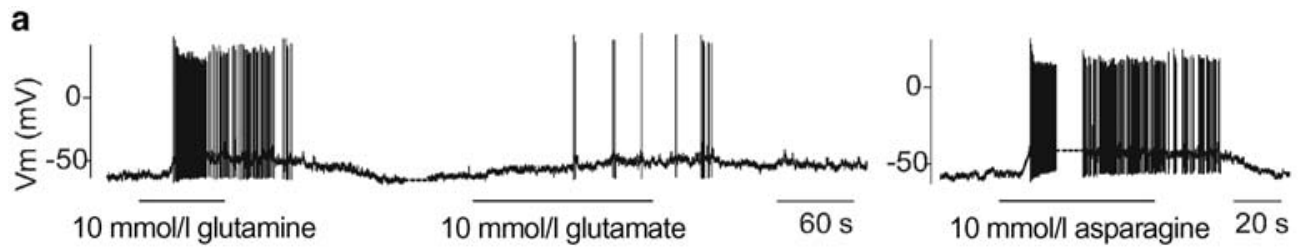

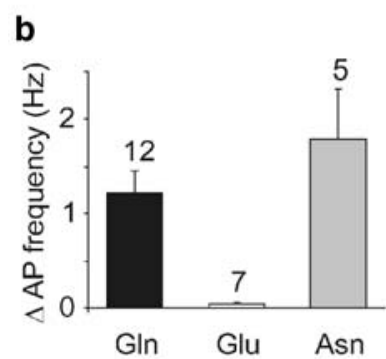

Fig. 2. Electrophysiological responses of GLUTag cells to glutamine. a. Action potentials triggered by glutamine, glutamate and asparagine $(10 \mathrm{mmol} / \mathrm{l})$, as indicated. b. Mean change $(\Delta)$ in action potential (AP) frequency in $10 \mathrm{mmol} / \mathrm{l}$ glutamine (Gln), glutamate (Glu) and asparagine (Asn). The numbers of cells analysed are indicated above the bars. c. Current (I)-voltage $(\mathrm{Vm})$ relationship in the presence and absence of
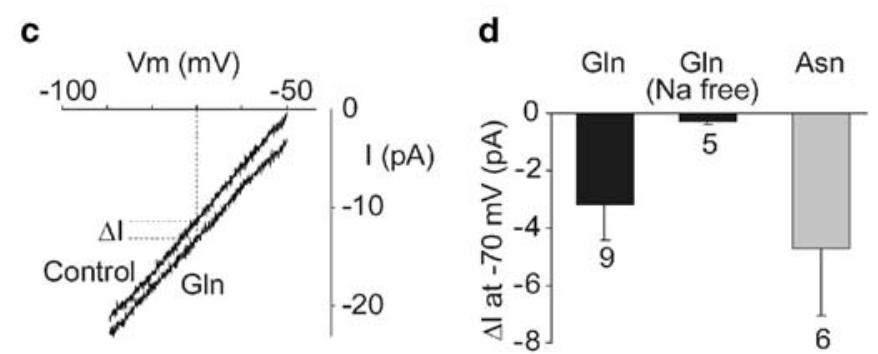

$10 \mathrm{mmol} / \mathrm{l}$ glutamine. The lines represent the means of more than ten voltage ramps in a single GLUTag cell. $\Delta \mathrm{I}$ represents the incremental current induced at $-70 \mathrm{mV}$. d. Mean $\Delta \mathrm{I}$ induced by $10 \mathrm{mmol} / \mathrm{l}$ glutamine (Gln) in the presence or absence (Na free) of extracellular sodium, or $10 \mathrm{mmol} / \mathrm{l}$ asparagine (Asn). The number of cells is given below each bar 
a

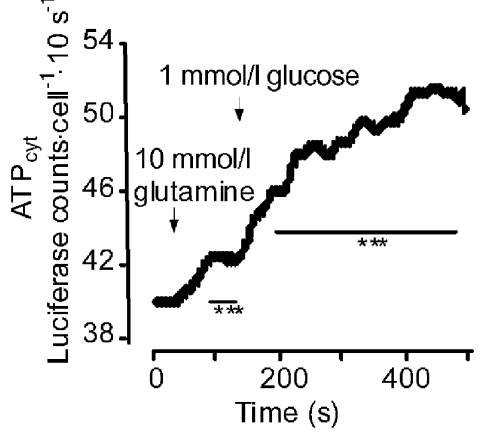

b

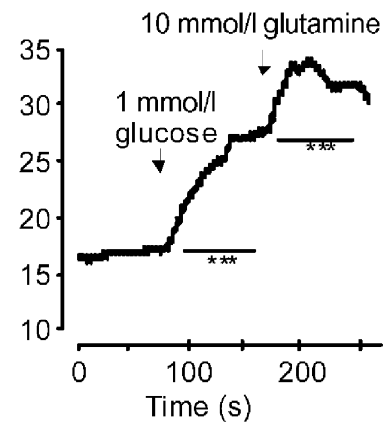

C

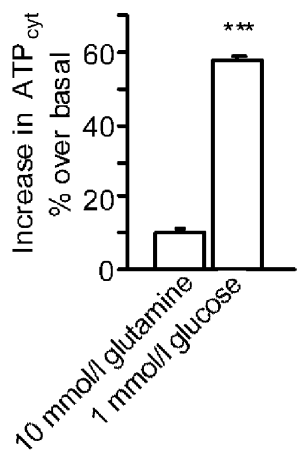

Fig. 3. Metabolic response of GLUTag cells to glutamine and glucose. a, b. Cytosolic-free ATP $\left(\mathrm{ATP}_{\text {cyt }}\right)$ was measured in cells cultured in $\mathrm{KRB}$ containing $0 \mathrm{mmol} / 1$ glucose, following the addition of $10 \mathrm{mmol} / \mathrm{l}$ glutamine and then $1 \mathrm{mmol} / \mathrm{l}$ glucose (a), or with the additions in reverse order (b). c. Mean change (\%) in cytosolic ATP resulting when glutamine or glucose were added first, as determined in the experiments shown in a and $\mathbf{b}$. Data are the means $\pm \mathrm{SE}$ of three individual experiments, with analysis of a minimum of 15 cells per experiment. $* * * p<0.001$ for the effects of indicated additions vs basal light output $(\mathbf{a}, \mathbf{b})$ or vs the effect of glutamine (c)

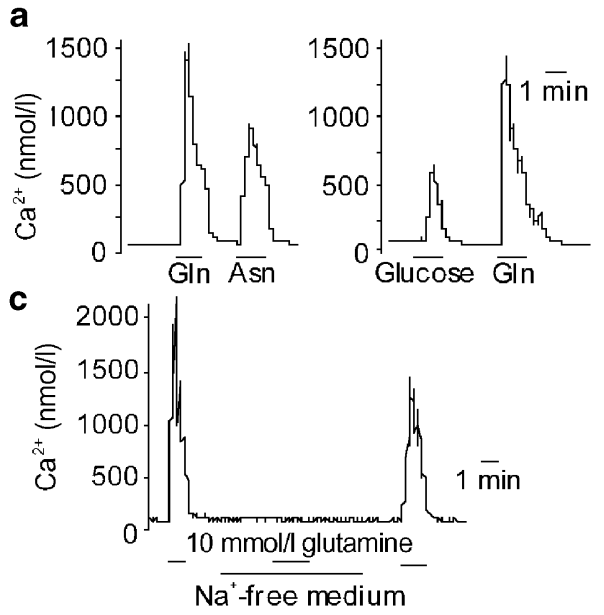

Fig. 4. Intracellular $\mathrm{Ca}^{2+}$ responses of GLUTag cells to glutamine. a. Cytoplasmic $\mathrm{Ca}^{2+}$ concentration in response to $10 \mathrm{mmol} / \mathrm{l}$ glutamine (Gln), asparagine (Asn) or glucose, as indicated. b. Mean $\left[\mathrm{Ca}^{2+}\right]_{\mathrm{i}}$ measured during a 30 -s period before, during and after application of $10 \mathrm{mmol} / \mathrm{l}$ glucose, MeAIB, asparagine or glutamine. Where filled bars are not marked with asterisks, results were not significant. ${ }^{*} p<0.01, * * * p<0.001$ vs glutamine. Open bars, control; filled bars, secretagogue. c. $\left[\mathrm{Ca}^{2+}\right]_{\mathrm{i}}$ changes in response to $10 \mathrm{mmol} / \mathrm{l}$ glutamine in the presence and absence ( $\mathrm{Na}^{+}$-free medium) of extracellular sodium. d. Mean $\left[\mathrm{Ca}^{2+}\right]_{\mathrm{i}}$ measured over $30 \mathrm{~s}$, as in c, in the absence and presence of glutamine. The response was measured initially in the presence of $\mathrm{Na}^{+}\left(\mathrm{Na}^{+}{ }_{\text {before }}\right)$, then during substitution of extracellular $\mathrm{Na}^{+}$with $\mathrm{NMDG}^{+}\left(\mathrm{NMDG}^{+}\right)$, and finally in the presence of $\mathrm{Na}^{+}$again $\left(\mathrm{Na}^{+}{ }_{\text {after }}\right)$. Open bars, control; filled bars, glutamine. $* p<0.05, * * * p<0.001$ vs mean of $\left[\mathrm{Ca}^{2+}\right]_{\mathrm{i}}$ measured before and after application of the amino acid. The number of analysed cells is given above each bar

response to $1 \mathrm{mmol} / \mathrm{l}$ glucose was approximately fivefold greater than the response to $10 \mathrm{mmol} / \mathrm{l}$ glutamine (Fig. 3c) when only the effects of the initial nutrient addition were compared.

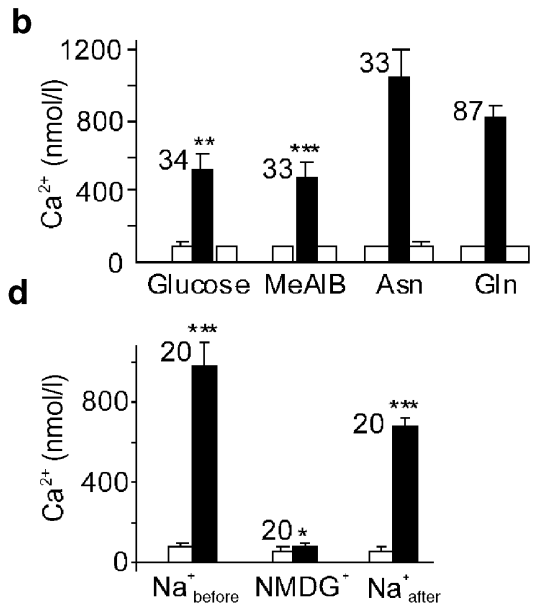

Intracellular calcium transients. In other neuroendocrine cell types such as pancreatic beta cells, the link between electrical activity and exocytosis is provided by calcium, which enters the cells through L-type voltage-gated $\mathrm{Ca}^{2+}$ channels [29]. We therefore investigated whether amino acids and glucose trigger a rise in intracellular $\mathrm{Ca}^{2+}$ in GLUTag cells. Cells were loaded by incubation with fura2-AM, and the fluorescence ratio at 340 and $380 \mathrm{~nm}$ was followed during application of test agents. Glutamine $(10 \mathrm{mmol} / \mathrm{l})$ triggered a reversible increase in $\left[\mathrm{Ca}^{2+}\right]_{\mathrm{i}}$ (Fig. 4a). In contrast, glucose triggered a smaller response and asparagine a comparable response to glutamine (Fig. 4a, b). The response to $10 \mathrm{mmol} / \mathrm{l}$ alanine was much stronger than that to glutamine, and was too large to measure accurately due to saturation of the fura-2. Substitution of extracellular $\mathrm{Na}^{+}$by $\mathrm{NMDG}^{+}$abolished the glutamine-induced rise in $\left[\mathrm{Ca}^{2+}\right]_{i}$ (Fig. $\left.4 c, d\right)$.

Expression of sodium-dependent glutamine transporters. The sodium dependency of the glutamine-induced inward current and calcium transient, taken 


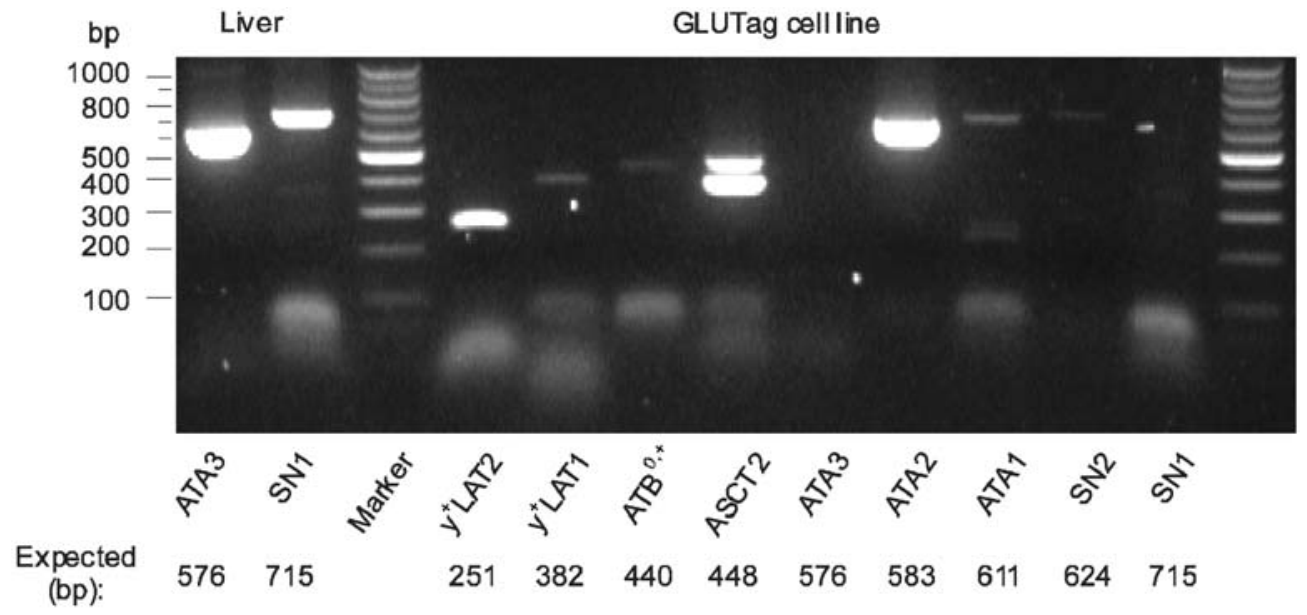

Fig. 5. Sodium-dependent glutamine transporter expression in the GLUTag cell line (RT-PCR). Positive controls (using mouse liver cDNA) for SN1 and ATA3, which were not detected in GLUTag cells, are shown on the left. Predicted band sizes are indicated. The non-specific lower band in the ASCT2 lane was also amplified with control cDNA from small intestine, and originates from a genomic sequence on murine chromosome 14

Table 1. Effect of candidate inhibitors on basal and stimulated GLP-1 release

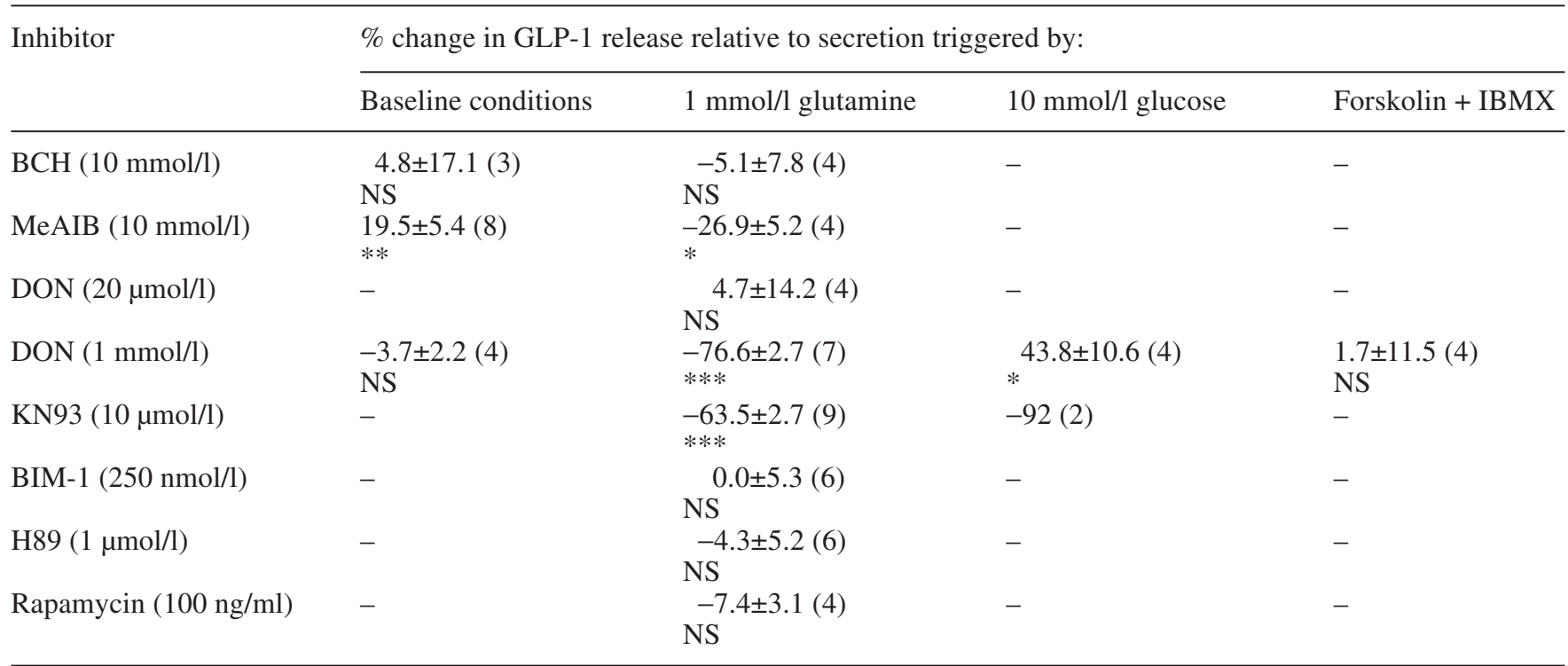

Data are presented as means $\pm \operatorname{SEM}(n)$. Significance was evaluated using Student's one-sample $t$ test, compared with zero (no change). NS, not significant; ${ }^{*} p<0.05 ; * * p<0.01 ; * * *<<0.001$. Negative values represent inhibition of secretion

together with the similarity of the responses induced by asparagine, suggest a possible involvement of $\mathrm{Na}-$ coupled amino acid transporters. We therefore used RT-PCR to identify which Na-coupled glutamine transporters [30] are expressed in GLUTag cells. The mRNA for several sodium-coupled glutamine transporters was detected (Fig. 5). The strongest bands were for ATA-2 (system A: an electrogenic, $\mathrm{Na}^{+}$-coupled neutral amino acid transporter), ASCT-2 (a nonelectrogenic $\mathrm{Na}^{+}$-coupled neutral amino acid transporter) and $\mathrm{y}^{+}$LAT2 (an $\mathrm{Na}^{+}$-coupled amino acid exchanger). Weaker bands were detected for SN2, ATA-1, ATB ${ }^{0+}$, and $\mathrm{y}^{+} \mathrm{LAT} 1$. One of the characteristics of system $\mathrm{A}$ is its ability to transport the amino acid analogue MeAIB. Consistent with the idea that system A contributes to electrogenic glutamine uptake in GLUTag cells, MeAIB $(10 \mathrm{mmol} / \mathrm{l})$ induced calcium transients in GLUTag cells that were smaller than those triggered by glutamine (Fig. 4a), triggered a small but significant increase in GLP-1 secretion, and reduced the secretory response to $1 \mathrm{mmol} / \mathrm{l}$ glutamine by approximately $25 \%$ (Table 1 ).

Additional effects of glutamine. The results of the electrophysiological and calcium imaging experiments suggest that the efficacy of glutamine as a GLP-1 secretagogue, compared with that of other amino acids such as asparagine and alanine, cannot be explained 
by differences in the magnitude of the depolarising current or calcium transient. An alternative possibility, therefore, is that glutamine in some way potentiates the secretory response, analogous to the effect of glucose on pancreatic beta cells [31]. To investigate this possibility, we compared the effects of glutamine, glucose and alanine on GLP-1 secretion in the presence of $30 \mathrm{mmol} / \mathrm{l} \mathrm{KCl}+$ diazoxide $(340 \mu \mathrm{mol} / \mathrm{l})$. Under these conditions the potassium current through open $\mathrm{K}_{\text {ATP }}$ channels produces a clamped membrane de-

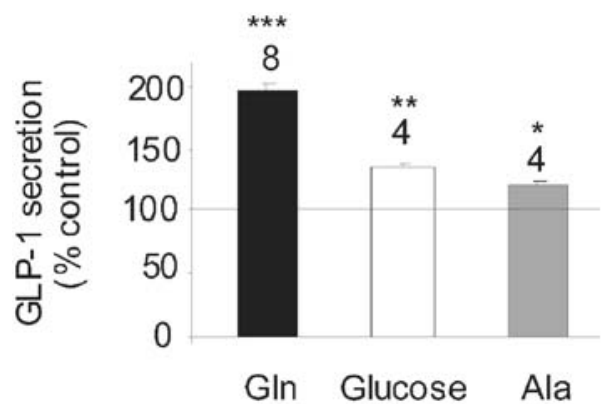

Fig. 6. Effects of glutamine independent of the plasma membrane potential. GLP-1 secretion measured in $30 \mathrm{mmol} / \mathrm{l}$ $\mathrm{KCl} / 340 \mu \mathrm{mol} / \mathrm{l}$ diazoxide and $10 \mathrm{mmol} / \mathrm{l}$ of glutamine $(\mathrm{Gln})$, glucose or alanine (Ala) as indicated. Secretion was normalised to that measured in the absence of nutrient on the same day (mean 301 $\pm 45 \mathrm{fmol} \cdot \mathrm{well}^{-1} \cdot 2 \mathrm{~h}^{-1} ; n=8$ ). Statistical significance was assessed relative to secretion in the absence of nutrients using Student's one-sample $t$ test: $* * * p<0.001$, $* * p<0.01, * p<0.05$

a

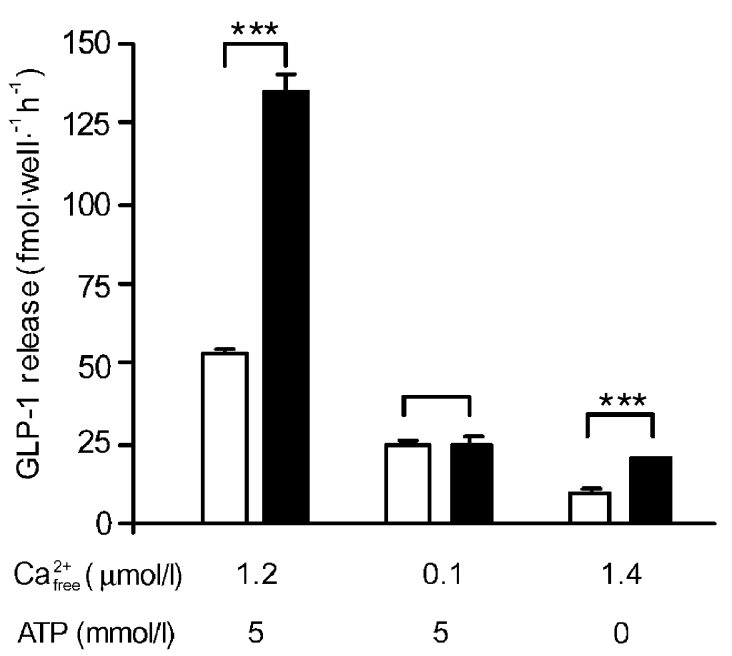

Fig. 7. Effects of glutamine and its metabolites in permeabilised cells. a. GLP-1 secretion from GLUTag cells permeabilised with $\alpha$-haemolysin and subsequently cultured with $10 \mathrm{mmol} / \mathrm{l}$ glutamine at concentrations of ATP and free $\mathrm{Ca}^{2+}$ (estimated using BAD4-software) as indicated. Open bars, no glutamine; closed bars, $10 \mathrm{mmol} / \mathrm{l}$ glutamine. $n=4$ for each condition. $* * * p<0.001$ vs no glutamine. Where bars are not marked with asterisks, results were not significant. b. GLP-1 secretion from permeabilised GLUTag cells in the presence of $5 \mathrm{mmol} / \mathrm{l} \mathrm{ATP,} 1.2 \mu \mathrm{mol} / \mathrm{l}$ free $\mathrm{Ca}^{2+}$ and $10 \mathrm{mmol} / \mathrm{l}$ glutamine polarisation that prevents small currents, such as those arising from electrogenic transporter activity, from significantly affecting the membrane potential. $30 \mathrm{mmol} / \mathrm{K} \mathrm{KCl}+$ diazoxide was itself a potent GLP-1 trigger, increasing secretion approximately six-fold. Glutamine doubled the secretory rate, whereas glucose and alanine induced significantly smaller effects (Fig. 6; $p<0.001$ vs glutamine for each). This suggests that glutamine enhances stages of the secretory pathway downstream of membrane depolarisation.

The major metabolites of glutamine in the gut are glutamate, proline, citrulline, ornithine and ammonium $[21,22]$. To investigate whether metabolism of glutamine via these pathways is required for the potentiation of GLP-1 release, we measured secretion in the presence of $\alpha$-haemolysin and fixed concentrations of ATP and free calcium. The advantages of this experimental design are that entry of the test agent occurs through membrane pores generated by the toxin and is not limited by the presence of appropriate transporters [32]. Only the secretory pathway downstream of the calcium signal is therefore tested. Glutamine (10 mmol/l) stimulated GLP-1 release 1.5 - to 2.3 -fold in the presence of elevated concentrations of ATP $(5 \mathrm{mmol} / \mathrm{l})$ and free $\mathrm{Ca}^{2+}(\sim 1 \mu \mathrm{mol} / \mathrm{l}$; Fig. 7). No glutamine-triggered secretion was observed at basal free $\mathrm{Ca}^{2+}$ concentrations $(\sim 100 \mathrm{nmol} / \mathrm{l})$, and hormone release was severely impaired by removal of ATP from the high- $\mathrm{Ca}^{2+}$ medium (Fig. 7a). Under stimulatory b

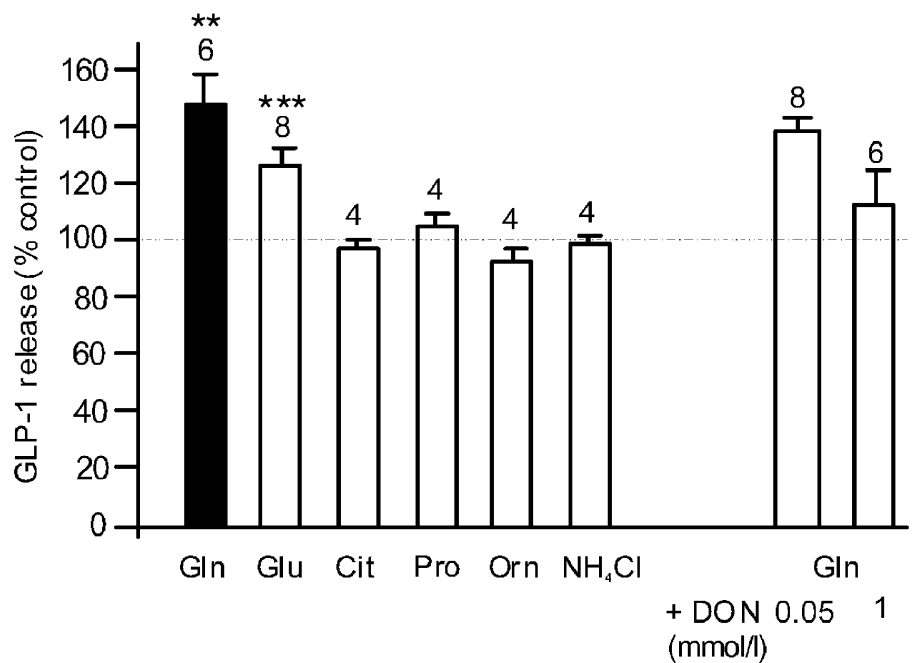

(Gln), glutamate (Glu), citrulline (Cit), proline (Pro), ornithine (Orn) or $1 \mathrm{mmol} / \mathrm{l}$ ammonium chloride as indicated, or with $10 \mathrm{mmol} / \mathrm{l}$ glutamine in the presence of DON $(50 \mu \mathrm{mol} / \mathrm{l}$ or $1 \mathrm{mmol} / \mathrm{l})$. Secretion was normalised to the baseline rate measured on the same day in the absence of nutrients (mean $\left.162 \pm 52 \mathrm{fmol} \cdot \mathrm{well}^{-1} \cdot \mathrm{h}^{-1} ; n=6\right)$. The number of wells is indicated above the bars. ${ }^{*} p<0.05, * * p<0.01, * * * p<0.001$ vs baseline or, in the case of DON, vs $10 \mathrm{mmol} / \mathrm{l}$ glutamine. Where bars are not marked with asterisks, results were not significant 
conditions (high free $\mathrm{Ca}^{2+}, 5 \mathrm{mmol} / \mathrm{l}$ ATP), glutamine was more effective than any of the metabolites tested (Fig. 7b).

We further investigated whether conversion to glutamate is required for the action of glutamine, by application of the glutaminase inhibitor DON in nonpermeabilised and $\alpha$-haemolysin-permeabilised cells. In non-permeabilised cells, $20 \mu \mathrm{mol} / \mathrm{l} \mathrm{DON}$ did not significantly affect the secretory response to $1 \mathrm{mmol} / \mathrm{l}$ glutamine, but $1 \mathrm{mmol} / \mathrm{l} \mathrm{DON}$ reduced the response by approximately $75 \%$ (Table 1 ). The inhibitory action of $1 \mathrm{mmol} / 1 \mathrm{DON}$ was specific to glutaminetriggered GLP-1 release, as it impaired neither basal secretion nor secretion triggered by $10 \mathrm{mmol} / \mathrm{l}$ glucose or forskolin plus IBMX $(10 \mu \mathrm{mol} / \mathrm{l}$ each). In $\alpha$-haemolysin-permeabilised cells, the response to $10 \mathrm{mmol} / \mathrm{l}$ glutamine was also inhibited by high, but not low, concentrations of DON (Fig. 7b). While low concentrations of DON block glutaminase in pancreatic beta cells [33], higher concentrations also block a range of other glutamine-utilising pathways [34]. In support of the lack of importance of carbon entry into the citric acid cycle via glutamate dehydrogenase $(\mathrm{GDH})$, the response to $1 \mathrm{mmol} / \mathrm{l}$ glutamine in non-permeabilised cells was not significantly affected by the allosteric GDH activator $\mathrm{BCH}(10 \mathrm{mmol} / \mathrm{l}$; Table 1).

To investigate whether specific protein kinases were necessary for the response to glutamine, we applied a range of kinase inhibitors (Table 1). The PKA inhibitor H-89 did not significantly affect glutaminetriggered GLP-1 release, suggesting that the response does not involve raised cAMP levels. This was further supported by the finding that the additional enhancement of secretion by glutamine was maintained in the presence of $10 \mu \mathrm{mol} / \mathrm{l}$ forskolin plus $10 \mu \mathrm{mol} / \mathrm{l}$ IBMX (4.5-fold increase by $10 \mathrm{mmol} / \mathrm{l}$ glutamine vs 3.0 -fold increase by $25 \mathrm{mmol} / \mathrm{l}$ glucose; from a baseline secretory rate of $139 \pm 12 \mathrm{fmol} \cdot \mathrm{well}^{-1} \cdot 2 \mathrm{~h}^{-1}$ in forskolin/ IBMX alone). The PKC inhibitor BIM-1 also had no effect on glutamine-induced secretion. Inhibition of CaM kinase by KN-93 reduced the response to glutamine by approximately $60 \%$, but the effect was not specific to glutamine, as KN-93 similarly impaired the secretory responses to glucose and alanine (data not shown). We also tested whether the intracellular amino acid target mTOR (mammalian target of rapamycin) played a role [35], by addition of $100 \mathrm{ng} / \mathrm{ml}$ rapamycin. This did not, however, significantly impair the response to glutamine.

\section{Discussion}

Our results show that glutamine is a potent stimulus of GLP-1 secretion from GLUTag cells. The median effective concentration was approximately $0.5 \mathrm{mmol} / \mathrm{l}$, close to the normal plasma glutamine concentration
[36], suggesting that physiological changes in glutamine following a meal could modulate GLP-1 release. Glutamine acted as both an initiator and a potentiator of secretion. The initiating stimulus triggered membrane depolarisation and action potential generation. However, the markedly potent effect of glutamine on secretion, compared with other amino acids or glucose, appears to be attributable to its ability to potentiate later stages of the secretory pathway. The ability of glutamine to stimulate GLP-1 secretion within 5 minutes of its application suggests that it acts by enhancing the release of preformed secretory vesicles.

Triggering pathway. Glutamine triggered GLP-1 release from GLUTag cells by generating a depolarising current of approximately $3 \mathrm{pA}$ per cell. As the typical membrane resistance of GLUTag cells was 2 to $5 \mathrm{G} \Omega$, this would be sufficient to depolarise the cells by approximately 5 to $15 \mathrm{mV}$, thereby initiating action potential firing and calcium entry. Both the glutamineinduced inward current and the calcium transient were mimicked using $10 \mathrm{mmol} / \mathrm{l}$ asparagine and abolished by extracellular sodium removal. Taken together with the ability of MeAIB to induce calcium transients and GLP-1 release, and the results of the RT-PCR, these findings suggest that electrogenic glutamine entry via ATA-2 contributes to the depolarising action of these amino acids. The $10 \mathrm{mmol} / \mathrm{l} \mathrm{MeAIB}$ also inhibited GLP-1 secretion in response to $1 \mathrm{mmol} / 1$ glutamine, albeit only partially. This might be explained by the competitive nature of this inhibitor and also by the fact that GLUTag cells express a number of other glutamine-carrying transporters. ASCT- 2 and $\mathrm{y}^{+} \mathrm{LAT} 2$, for example, gave strong RT-PCR bands and might therefore play a role in total glutamine uptake, although both of these transporters catalyse electroneutral amino acid exchange [30, 37] and would not, therefore, directly contribute to membrane depolarisation. The increase in intracellular $\mathrm{Ca}^{2+}$ from approximately $100 \mathrm{nmol} / 1$ to approximately 600 to $1000 \mathrm{nmol} / \mathrm{l}$, triggered by glucose, glutamine and asparagine, is similar to that which triggers exocytosis in other secretory cells.

Amplifying pathway. The efficacy of glutamine in stimulating GLP-1 release cannot be accounted for by its depolarising action only, as asparagine and alanine were less effective as secretagogues even though they induced currents and calcium transients that were, if anything, larger than those produced by glutamine. The idea that glutamine has an independent effect on secretion was supported by further experiments carried out under conditions that eliminate the effects of small depolarising currents. Measuring secretion in the presence of diazoxide and a depolarising concentration of $\mathrm{KCl}(30 \mathrm{mmol} / \mathrm{l})$ is routinely used to demonstrate an amplifying effect of glucose on insulin release [31]. Under these conditions, glutamine still en- 
hanced GLP-1 release more effectively than glucose or alanine.

To investigate whether glutamine metabolites were responsible for the amplifying action of glutamine, we measured GLP-1 secretion in cells permeabilised by $\alpha$-haemolysin. In permeabilised cells with fixed stimulatory concentrations of free $\mathrm{Ca}^{2+}$ and ATP, glutamine remained a potent trigger of secretion. This action was severely impaired by removal of ATP or reduction of the free $\mathrm{Ca}^{2+}$ concentration to basal levels. The principal gastrointestinal metabolites of glutamine (glutamate, proline, ornithine, citrulline and ammonium) [21] were less effective or inactive as secretagogues, suggesting that metabolism via these pathways is not responsible for the amplifying action of glutamine. This is supported by the finding that low concentrations of DON did not markedly impair the response. The metabolic generation of ATP is also unlikely to be directly implicated, as ATP levels were elevated less by glutamine than by glucose. Furthermore, $\mathrm{BCH}$, which activates glutamate dehydrogenase and enhances carbon flux from glutamate into the citric acid cycle, did not enhance GLP-1 secretion in the presence of glutamine. The results suggest that the potentiating effect of glutamine is mediated either by the amino acid itself or by the product of a different metabolic pathway. Similar, but not identical, conclusions have been reached in studies investigating a role for glutamine in insulin secretion from pancreatic beta cells $[33,38]$.

Although PKA and PKC have been previously shown to play a role in GLP-1 secretion from GLUTag cells [39], inhibition of these protein kinases did not affect glutamine-stimulated secretion. Application of the CaM kinase inhibitor KN93 impaired the action of glutamine, glucose and alanine, suggesting that it acts at a common step in the secretory pathway. However, previous results show that the related CaM kinase inhibitor KN62 also blocks L-type Ca-channels [40].

Physiological significance. Glutamine is the major metabolic fuel of the gut and has been shown to have beneficial effects on gut integrity. It is therefore perhaps not surprising that it has such a profound effect on GLP-1 release. If the concentration dependence of GLP-1 release in vivo mirrors that observed in GLUTag cells, the glutamine content of a meal could provide a significant stimulus to the $\mathrm{L}$ cells. Indeed, it has been shown that glutamine significantly increased PYY release after small bowel resection in rats [41]. Studies are now required to test whether glutamine stimulates or potentiates GLP-1 release in vivo, and whether glutamine supplementation could be used as a nutritional therapy to enhance GLP-1 and PYY concentrations in diabetic and obese subjects. A further interesting question is whether enhanced GLP-2 concentrations, which might occur following glutamine supplementation, contribute to the positive effect of glutamine on gut function.

Acknowledgements. We thank Daniel Drucker (Toronto) for permission to work with GLUTag cells. F. M. Gribble is a Wellcome Trust Senior Research Fellow in Clinical Science and F. Reimann is a Diabetes UK R. D. Lawrence Fellow. Their work was also supported by the equipment grant BDA:RD02/0002539. G. A. Rutter was supported by a Research Leave Fellowship and a Project (062321) and Programme Grant (067081/Z/02/Z) from the Wellcome Trust.

\section{References}

1. Drucker DJ (2002) Biological actions and therapeutic potential of the glucagon-like peptides. Gastroenterology 122:531-544

2. Kieffer TJ, Habener JF (1999) The glucagon-like peptides. Endocrine Rev 20:876-913

3. Adrian TE, Ferri GL, Bacarese-Hamilton AJ et al. (1985) Human distribution and release of a putative new gut hormone, peptide YY. Gastroenterology 89:1070-1077

4. Ritzel U, Fromme A, Ottleben M, Leonhardt U, Ramadori G (1997) Release of glucagon-like peptide-1 (GLP-1) by carbohydrates in the perfused rat ileum. Acta Diabetol 34:18-21

5. Plaisancie P, Dumoulin V, Chayvialle JA, Cuber JC (1995) Luminal glucagon-like peptide-1(7-36) amide-releasing factors in the isolated vascularly perfused rat colon. J Endocrinol 145:521-526

6. Anini Y, Fu-Cheng X, Cuber JC et al. (1999) Comparison of the postprandial release of peptide YY and proglucagonderived peptides in the rat. Pflugers Arch 438:299-306

7. Gromada J, Holst JJ, Rorsman P (1998) Cellular regulation of islet hormone secretion by the incretin hormone glucagon-like peptide 1. Pflugers Arch 435:583-594

8. Batterham RL, Cowley MA, Small CJ et al. (2002) Gut hormone PYY(3-36) physiologically inhibits food intake. Nature 418:650-654

9. Drucker DJ (2002) Gut adaptation and the glucagon-like peptides. Gut 50:428-435

10. Elliott RM, Morgan LM, Tredger JA et al. (1993) Glucagon-like peptide-1 (7-36) amide and glucose-dependent insulinotropic polypeptide secretion in response to nutrient ingestion in man: acute post-prandial and 24-h secretion patterns. J Endocrinol 138:159-166

11. Herrmann C, Göke R, Richter G et al. (1995) Glucagonlike peptide-1 and glucose-dependent insulin-releasing polypeptide plasma levels in response to nutrients. Digestion 56:117-126

12. Fu-Cheng X, Anini Y, Chariot J et al. (1995) Peptide YY release after intraduodenal, intraileal, and intracolonic administration of nutrients in rats. Pflugers Arch 431:66-75

13. Rocca AS, Brubaker PL (1999) Role of the vagus nerve in mediating proximal nutrient-induced glucagon-like peptide-1 secretion. Endocrinology 140:1687-1694

14. Reimann F, Gribble FM (2002) Glucose sensing in GLP-1 secreting cells. Diabetes 51:2757-2763

15. Gribble FM, Williams L, Simpson AK, Reimann F (2003) A novel glucose-sensing mechanism contributing to Glucagon-Like Peptide-1 secretion from the GLUTag cell line. Diabetes 52:1147-1154

16. Hall WL, Millward DJ, Long SJ, Morgan LM (2003) Casein and whey exert different effects on plasma amino acid profiles, gastrointestinal hormone secretion and appetite. Br J Nutr 89:239-248 
17. Xiao Q, Boushey RP, Drucker DJ, Brubaker PL (1999) Secretion of the intestinotropic hormone glucagon-like peptide 2 is differentially regulated by nutrients in humans. Gastroenterology 117:99-105

18. Layer P, Holst JJ, Grandt D, Goebell H (1995) Ileal release of glucagon-like peptide-1 (GLP-1). Association with inhibition of gastric acid secretion in humans. Dig Dis Sci 40:1074-1082

19. Dumoulin V, Moro F, Barcelo A, Daka T, Cuber JC (1998) Peptide YY, glucagon-like peptide-1, and neurotensin responses to luminal factors in the isolated vascularly perfused rat ileum. Endocrinology 139:3780-3786

20. Cordier-Bussat M, Bernard C, Levenez F et al. (1998) Peptones stimulate both the secretion of the incretin hormone glucagon-like peptide 1 and the transcription of the proglucagon gene. Diabetes 47:1038-1045

21. Windmueller HG (1982) Glutamine utilization by the small intestine. Adv Enzymol 53:201-237

22. Reeds PJ, Burrin DG (2001) Glutamine and the bowel. J Nutr 131:2505S-2508S

23. Wilmore DW (1997) Metabolic support of the gastrointestinal tract: potential gut protection during intensive cytotoxic therapy. Cancer 79:1794-1803

24. Drucker DJ, Jin T, Asa SL, Young TA, Brubaker PL (1994) Activation of proglucagon gene transcription by protein kinase $\mathrm{A}$ in a novel mouse enteroendocrine cell line. Mol Endocrinol 8:1646-1655

25. Brooks SP, Storey KB (1992) Bound and determined: a computer program for making buffers of defined ion concentrations. Anal Biochem 201:119-126

26. Grynkiewicz G, Poenie M, Tsien RY (1985) A new generation of $\mathrm{Ca}^{2+}$ indicators with greatly improved fluorescence properties. J Biol Chem 260:3440-3450

27. Ainscow EK, Rutter GA (2001) Mitochondrial priming modifies $\mathrm{Ca}^{2+}$ oscillations and insulin secretion in pancreatic islets. Biochem J 353:175-180

28. Kennedy HJ, Pouli AE, Ainscow E et al. (1999) Glucoseinduced ATP microdomains in single islet $\beta$-cells: role for strategically located mitochondria. J Biol Chem 274:1328113291

29. Rorsman P (1997) The pancreatic beta-cell as a fuel sensor: an electrophysiologist's viewpoint. Diabetologia 40:487-495
30. Bode BP (2001) Recent molecular advances in mammalian glutamine transport. J Nutr 131:2475S-2485S

31. Henquin JC (2000) Triggering and amplifying pathways of regulation of insulin secretion by glucose. Diabetes 49:1751-1760

32. Maechler P, Kennedy ED, Pozzan T, Wollheim CB (1997) Mitochondrial activation directly triggers the exocytosis of insulin in permeabilized pancreatic $\beta$-cells. EMBO J 16:3833-3841

33. Li C, Buettgers C, Kwagh J et al. (2004) A signalling role for glutamine in insulin secretion. J Biol Chem 279:13393-13401

34. Ahluwalia GS, Grem JL, Hao Z, Cooney DA (1990) Metabolism and action of amino acid analog anti-cancer agents. Pharmacol Ther 46:243-271

35. Xia Y, Wen HY, Young ME et al. (2003) Mammalian target of rapamycin and protein kinase A signalling mediate the cardiac transcriptional response to glutamine. J Biol Chem 278:13143-13150

36. Cynober LA (2002) Plasma amino acid levels with a note on membrane transport: characteristics, regulation and metabolic significance. Nutrition 18:761-766

37. Broeer S (2002) Adaptation of plasma membrane amino acid transport mechanisms to physiological demands. Pflugers Arch 444:457-466

38. Kelly A, Li C, Gao Z, Stanley CA, Matschinsky FM (2002) Glutaminolysis and insulin secretion: from bedside to bench and back. Diabetes 51:S421-S426

39. Brubaker PL, Schloos J, Drucker DJ (1998) Regulation of glucagons-like peptide-1 synthesis and secretion in the GLUTag enteroendocrine cell line. Endocrinology 139:41084114

40. Li G, Hidaka H, Wollheim CB (1992) Inhibition of voltage-gated $\mathrm{Ca}^{2+}$ channels and insulin secretion in HIT cells by $\mathrm{Ca}^{2+} /$ calmodulin-dependent protein kinase inhibitor KN62: comparison with antagonists of calmodulin and L-type $\mathrm{Ca}^{2+}$ channels. Mol Pharmacol 42:489498

41. Wiren M, Adrian TE, Arnelo U et al. (1999) Early gastrointestinal regulatory peptide response to intestinal resection in the rat is stimulated by enteral glutamine supplementation. Dig Surg 16:197-203 